\title{
Organic acids and 2,4-Di-tert-butylphenol: Major compounds of Weissella confusa WM36 cell-free supernatant against growth, survival and virulence of Salmonella Typhi
}

\author{
Wattana Pelyuntha $^{\text {Corresp., } 1}$, Chaiyavat Chaiyasut ${ }^{1}$, Duangporn Kantachote ${ }^{2}$, Sasithorn Sirilun ${ }^{\text {Corresp. } 1}$ \\ ${ }^{1}$ Innovation Center for Holistic Health, Nutraceuticals and Cosmeceuticals, Faculty of Pharmacy, Chiang Mai University, Chiang Mai, Thailand \\ 2 Department of Microbiology, Faculty of Science, Prince of Songkla University, Hat Yai, Thailand \\ Corresponding Authors: Wattana Pelyuntha, Sasithorn Sirilun \\ Email address: wattana_p@cmu.ac.th, sasithorn.s@cmu.ac.th
}

Background. Salmonella Typhi (S. Typhi), the causative agent of typhoid fever, causes serious systemic disease in humans. Antibiotic treatment is required for the $S$. Typhi infection, while the inappropriate use of antibiotics causes increased drug-resistant $S$. Typhi. Hence, alternative therapies through nonantibiotic approaches are urgently needed. The use of beneficial lactic acid bacterium and/or its metabolites to control typhoid fever represent a promising approach, as it may exert protective actions through various mechanisms.

Method. In this study, the cell-free culture supernatant (CFCS) of Weissella confusa WM36 was evaluated via the antibacterial activity, and its metabolites were identified. In addition, the effects of CFCS on Salmonella virulence behaviors were also investigated.

Result. Based on strong inhibition the growth of $S$. Typhi DMST 22842, organic acids (lactic acid and acetic acid) and 2,4-Di-tert-butylphenol (2,4 DTBP), were the main antibacterial metabolites presented in CFCS of strain WM36. Minimum inhibitory concentration (MIC) at 40\% WM36-CFCS dramatically reduced the $S$. Typhi population to more than $99.99 \%$ at $4 \mathrm{~h}$ and completely inhibited biofilm formation, while subMIC at $20 \%(\mathrm{v} / \mathrm{v})$ and MIC could reduce $100 \%$ of motility. Additionally, sub-MIC at only $10 \%(\mathrm{v} / \mathrm{v})$ WM36CFCS did down-regulate the expression of virulence genes which are responsible for the type-III secretion system, effector proteins, and quorum sensing (QS) system in this pathogen.

Conclusion. W. confusa WM36 and its metabolites are shown to be a promising candidates, and an effective approach against typhoid Salmonella burden. 


\section{Organic acids and 2,4-Di-tert-butylphenol: Major}

2 compounds of Weissella confusa WM36 Cell-free

3 Supernatant Against Growth, Survival and Virulence

4 of Salmonella Typhi

Wattana Pelyuntha ${ }^{1}$, Chaiyavat Chaiyasut ${ }^{1}$, Duangporn Kantachote ${ }^{2}$, Sasithorn Sirilun ${ }^{1}$

${ }^{1}$ Innovation Center for Holistic Health, Nutraceuticals and Cosmeceuticals, Faculty of

9 Pharmacy, Chiang Mai University, Chiang Mai 50200, Thailand

${ }^{2}$ Department of Microbiology, Faculty of Science, Prince of Songkla University, Hat Yai 90112,

11 Thailand

Corresponding Author:

Sasithorn Sirilun ${ }^{1}$

Innovation Center for Holistic Health, Nutraceuticals and Cosmeceuticals, Faculty of Pharmacy,

Email address: sasithorn.s@cmu.ac.th

\section{Abstract}

Background. Salmonella Typhi (S. Typhi), the causative agent of typhoid fever, causes serious systemic disease in humans. Antibiotic treatment is required for the $S$. Typhi infection, while the inappropriate use of antibiotics causes increased drug-resistant $S$. Typhi. Hence, alternative therapies through non-antibiotic approaches are urgently needed. The use of beneficial lactic acid bacterium and/or its metabolites to control typhoid fever represent a promising approach, as it may exert protective actions through various mechanisms.

Method. In this study, the cell-free culture supernatant (CFCS) of Weissella confusa WM36 was evaluated via the antibacterial activity, and its metabolites were identified. In addition, the effects of CFCS on Salmonella virulence behaviors were also investigated.

Result. Based on strong inhibition the growth of $S$. Typhi DMST 22842, organic acids (lactic acid and acetic acid) and 2,4-Di-tert-butylphenol (2,4 DTBP), were the main antibacterial metabolites presented in CFCS of strain WM36. Minimum inhibitory concentration (MIC) at $40 \%$ WM36-CFCS dramatically reduced the $S$. Typhi population to more than $99.99 \%$ at $4 \mathrm{~h}$ and completely inhibited biofilm formation, while sub-MIC at $20 \%(\mathrm{v} / \mathrm{v})$ and MIC could reduce $100 \%$ of motility. Additionally, sub-MIC at only $10 \%$ (v/v) WM36-CFCS did down-regulate the expression of virulence genes which are responsible for the type-III secretion system, effector proteins, and quorum sensing (QS) system in this pathogen. 
39

40

41

42

43

44

45

46

47

48

49

50

51

52

53

54

55

56

57

58

59

60

61

62

63

64

65

66

67

68

69

70

71

72

73

74

75

76

77

78

79

80

81

82

\section{Introduction}

Typhoid fever is a serious bacterial infection caused by Salmonella enterica serotype Typhi ( $S$.

Typhi). This bacterium is transmitted through the consumption of contaminated foods and water (direct fecal-oral transmission) and infects only humans (de Jong et al., 2012). Worldwide, typhoid fever was estimated to have 12 million cases and 130,000 deaths in the year 2010 (John, Van Aart \& Grassly, 2016). It is a systemic disease of varying severity, with symptoms including a gradual onset of high fever, headaches, weakness, dry cough, abdominal pain or constipation. The severity of infections in humans depends on the health status of the human host. Young children, adults, and immunocompetent patients are more susceptible than healthy adults (Eng et al., 2015). S. Typhi invades the small intestine, enters the blood circulation, and survives within the phagocytic cells. This bacterium also colonizes the spleen, liver and bone marrow in infected humans. In addition, it invades the defense mechanisms to interrupt the host immune responses (Raffatellu et al., 2018).

$S$. Typhi pathogenesis relies mainly on the expression of genes within Salmonella pathogenicity islands (SPI); all islands have their own patterns of regulation and expression of their genes. SPI-1 is one of them and encoded for type-III secretion system (T3SS). The T3SS is a syringe-like molecule, that delivers bacterial effector proteins into the host cell to rearrange cytoskeleton to aid bacterial invasion, survival and multiplication in host cells (Kaur \& Jain, 2012; Marcus et al., 2000). Moreover, $S$. Typhi consists of other virulence factors including fimbriae, flagella, and biofilms, which are responsible for adherence, motility, and resistance to antibiotics, and bactericidal agents, respectively (de Jong et al., 2012). Additionally, quorum sensing (QS) systems have been described in Salmonella virulence, these systems work as a signaling network to control the expression of behaviors, especially virulence gene expression. SPI-1 genes and biofilm of Salmonella are believed to be controlled by QS systems (Pui et al., 2011).

Up to date antibiotic therapy is obligately required for the treatment of typhoid fever. The first line antibiotics suggested in healing illness including chloramphenicol, ampicillin, and trimethoprim-sulfamethoxazole (Mutai et al., 2018). Increased inappropriate use of first line drugs has resulted in the emergence of multidrug-resistant (MDR) $S$. Typhi. Fluoroquinolones and the third-generation drugs have become alternative treatments of typhoid fever, but these drugs can cause undesirable side effects (Veeraraghavan et al., 2018). The Center for Disease Control and Prevention (CDC) ranks the incidence of typhoid fever that emerges by MDR-S. Typhi spread as a serious threat. Monitoring and preventing programs are required to reduce the spread of this resistant strain (Mutai et al., 2018). In this regard, the use of alternative therapies for controlling bacterial infections caused by antibiotic-resistant bacteria through the nonantibiotic approach is urgently needed for treatments.

Lactic acid bacteria (LAB) are presenting as a promising candidate, as it may exert protective actions through various mechanisms. LAB can modulate the host's immune system, compete for adhesion sites of pathogens on epithelial cells, and produce a variety of antimicrobials against many pathogenic microorganisms (Both et al., 2011). It has long been known that most LAB strains are recognized as safe (GRAS), and several strains used in food manufacturing and nutraceutical developments. They are normally found as a dominant normal flora in the gastrointestinal tracts of mammals, as well as in several types of fermented foods. LAB can utilize the sugars as a sole carbon source for energy and change into most organic acids 
83 as the natural preservatives in fermented foods. Hence, they are considered to be safe, and act as

84 a multifunctional agent in food production (Pandey, Naik \& Vakil, 2015). The antimicrobial

85 substances produced by LAB are divided into 2 groups based on molecular weight, low

86 molecular mass substances $(<1,000 \mathrm{Da})$ including organic acids, $\mathrm{H}_{2} \mathrm{O}_{2}$, acetoin, diacetyl,

87 acetaldehyde, etc., and high molecular mass substances ( $>1,000 \mathrm{Da})$ such as bacteriocins

88 (Šušković et al., 2015).

89 The lactic acid bacterial genus Weissella was proposed as a genus re-classified Lactobacillus

90 and Leuconostoc spp. This genus is frequently detected in several fermented foods (Fessard \&

91 Remize, 2017). Weissella confusa has been established from a variety of foods, such as

92 fermented vegetables and fruits; milk and milk products; and acid-rich carbohydrate foods.

93 However, it can also be isolated from the sewage and clinical samples, and this strain is believed

94 to be normal microflora in human gastrointestinal and urogenital tracts (Fusco et al., 2015). The

95 antagonistic activities of $W$. confusa on pathogenic bacteria including Bacillus cereus,

96 Escherichia coli, Helicobacter pylori, Proteus mirabilis, Pseudomonas aeruginosa, and

97 Staphylococcus aureus, have been described in several previous reports. W. confusa can produce

98 organic acids and bacteriocins in culture medium and some strain can strongly adhere to

99 intestinal epithelial cells (Chavasirikunton, Vatanyoopaisarn \& Phalakornkule, 2006; Lee, 2004;

100 Nam et al., 2002; Purkhayastha et al., 2017; Shah et al., 2016). An increasing number of LAB

101 and metabolite related, studies only focus on the properties of other LAB rather than Weissella

102 spp. isolates. W. confusa was therefore chosen in this study, and its antagonistic activities were

103 also examined to provide more information on LAB.

104

105

Organic acids are commonly characterized as antimicrobial substances produced by all LAB strains, while their amounts and types depend on LAB strains and activity in a culture medium.

106 Organic acids are effective at inhibiting the growth of Gram-positive and Gram-negative bacteria, which belong to yeasts and molds (Pessione, 2012; Rattanachaikunsopon \&

108 Phumkhachorn, 2010). Diacetyl, acetaldehyde, and acetoin are characterized as antimicrobial substances produced by a variety of heterofermentative LAB. These compounds are not the major antimicrobial substances, but they work together, along with other antimicrobial substances. $\mathrm{H}_{2} \mathrm{O}_{2}, \mathrm{CO}_{2}$, fatty acids, and cyclic dipeptides produced by LAB act as microbicide against Gram-negative and Gram-positive bacteria, yeasts, and molds (Dicks et al., 2018;

113 Pessione, 2012; Rattanachaikunsopon \& Phumkhachorn, 2010). Interestingly, one of the most identified antimicrobial substances produced by LAB is bacteriocins, which are secondary metabolites. Their main function is to inhibit or kill undesired microorganisms in food products and are safe food biopreservatives obviating the need for harmful chemical preservations (Dicks et al., 2018; Pessione, 2012; Rattanachaikunsopon \& Phumkhachorn, 2010; Silva, Silva \&

118 Ribeico, 2018). Moreover, LAB and their metabolites are not only used to extend the shelf-life of foods from spoilage microorganisms, but are also effective in the prevention and treatment of bacterial infections. There is ample diversity of literature supporting the efficacy of LAB and their metabolites on pathogenic microorganisms. Therefore, potent LAB strains provide a better alternative way to fight bacterial infections.

The objectives of this study are (i) to extract and evaluate the antagonistic activity of cellfree culture supernatant (CFCS) of $W$. confusa WM36 against the causative agents of typhoid fever, $S$. Typhi, (ii) to investigate the effect of WM36-CFCS on Salmonella growth, biofilm formation, motility and virulence gene expression in vitro, and (iii) to characterize the compounds of antimicrobial substances produced by WM36 strain using suitable methods via 
128 High-Performance Liquid Chromatography (HPLC) and Gas Chromatography-Mass

129 Spectrometry (GC-MS).

130

131

132

133

134

135

136

137

138

139

140

141

142

143

144

145

146

147

148

149

150

151

152

153

154

155

156

157

158

159

160

161

162

163

164

165

166

167

168

169

170

171

172

\section{Materials \& Methods}

\section{Bacterial strain and growth conditions}

W. confusa WM36 isolated from fermented grape was obtained from the Innovation Center for Holistic Health, Nutraceuticals and Cosmeceuticals, Faculty of Pharmacy, Chiang Mai University. W. confusa WM36 is permanently deposited in the Thailand Bioresource Research Center (TBRC), Pathum Thani, Thailand with the accession numbers TBRC11086. The WM36 was cultivated in de Man Rogosa and Sharpe (MRS) medium at $37^{\circ} \mathrm{C}$ overnight prior to analysis. Salmonella Typhi DMST 22842 used in this study was obtained from the Department of Pharmaceutical Science, Faculty of Pharmacy, Chiang Mai University, and was cultivated at $37^{\circ} \mathrm{C}$ in Luria-Bertani (LB) medium or tryptic soy broth (TSB).

\section{Preparation of $\boldsymbol{W}$. confusa WM36-CFCS}

To obtain CFCS, $W$. confusa WM36 was activated and cultured in the MRS broth at $37^{\circ} \mathrm{C}$ for 24 $\mathrm{h}$ with the final concentration number at $10^{6} \mathrm{CFU} / \mathrm{ml}$. CFCS was collected by centrifugation at $6,000 \mathrm{rpm}$ at $4{ }^{\circ} \mathrm{C}$ for $15 \mathrm{~min}$ and sterilized through a $0.22 \mu \mathrm{m}$ syringe filter and kept in $-20^{\circ} \mathrm{C}$.

\section{Antibacterial susceptibility test of CFCS}

The modified agar diffusion method described by Reis et al. (2016) was provided. S. Typhi was pre-cultured in tryptic soy broth (TSB) at $37^{\circ} \mathrm{C}$ for $18 \mathrm{~h}$. Then, the pathogen was diluted with $0.85 \%$ normal saline solution and yielded the final concentration at $10^{5} \mathrm{CFU} / \mathrm{ml}$ in TSA soft agar (1.0\% agar). A $20 \mathrm{ml}$ of soft agar mixture was poured into a sterile petri-dish containing stainless-steel carriers (5 $\mathrm{mm}$ in diameter). After setting of the agar medium, wells were formed by pulling out the carriers; $50 \mu \mathrm{L}$ of CFCS was dropped into each well ( 3 wells per plate). All plates were incubated at $37^{\circ} \mathrm{C}$ for $48 \mathrm{~h}$. The inhibitory zone in the vicinity of the well was observed and the diameter was measured with the Vernier caliper in millimeter measurement. 5 $\mathrm{mg} / \mathrm{mL}$ of ampicillin and fresh MRS broth served as the positive and negative control for this study.

For minimum inhibitory concentration (MIC) test, the broth microdilution method was performed to determine the MIC value of CFCS. The sterile CFCS was serially diluted in 96well round-bottom microtiter plates containing LB broth to yield the final concentrations ranging from $5 \%$ to $90 \%$ of CFCS. The inoculum of $S$. Typhi $(10 \mu \mathrm{L})$ containing $\sim 10^{5} \mathrm{CFU} / \mathrm{mL}$ was added to each well. The fresh LB broth well was reserved as the sterility control (no inoculum), and the inoculum viability (no CFCS) was served as a positive control. All microplates were incubated at $37^{\circ} \mathrm{C}$ for $24 \mathrm{~h}$. MIC values were defined as the lowest concentration of CFCS that had no visible growth (Ben Slama et al., 2013).

\section{Characterization of antimicrobial substances in CFCS}

To eliminate the antimicrobial effect of organic acids, WM36-CFCS was neutralized as $\mathrm{pH}$ to 7.0 with $1 \mathrm{~N} \mathrm{NaOH}$ to rule out acid inhibition, proteinase $\mathrm{K}$ and lysozyme to rule out proteinaceous substances inhibition, and catalase to rule out $\mathrm{H}_{2} \mathrm{O}_{2}$ inhibition. An antagonistic activity of these neutralizing CFCS was investigated using the agar well diffusion method as previously described. Untreated CFCS served as the control (Therdtatha et al., 2016). 
173

174

175

176

177

178

179

180

181

182

183

184

185

186

187

188

189

190

191

192

193

194

195

196

197

198

199

200

201

202

203

204

205

206

207

208

209

210

211

212

213

214

215

216

217

218

\section{pH, titratable acidity, and organic acid analysis}

The $\mathrm{pH}$ value of WM36-CFCS was measured with a $\mathrm{pH}$ meter. For the titratable acidity (TA) assay, $1 \mathrm{ml}$ of WM36-CFCS was diluted with $9 \mathrm{ml}$ of deionized water in $250 \mathrm{ml}$ of Erlenmeyer flask. Two drops of phenolphthalein solution were added as indicator. The mixture was titrated with standardized $\mathrm{NaOH}(\sim 0.1 \mathrm{~N})$ until a faint lasting pink color appeared and the titratable volume was recorded. TA was expressed as the percentage of lactic acid equivalent (\%LAE):

$(\% \mathrm{LAE})=[($ Normality of standardized $\mathrm{NaOH} \times$ Titratable volume of standardized $\mathrm{NaOH} \times 90)$ /sample volume x 1000] x100.

Lactic acid and acetic acid in WM36-CFCS were investigated by HPLC with the slightly modified method described by Lin et al. (2011). WM36-CFCS was diluted ten-fold with deionized water and filtered through $0.22 \mu \mathrm{m}$ syringe filter and kept in an autosampler vial. Aliquot of $20 \mu \mathrm{l}$ was injected into a 250x4.6 mm ACE Generix5 C18 column (ACE®, UK). Elution was performed at $30{ }^{\circ} \mathrm{C}$ with $0.1 \%$ phosphoric acid at a flow rate of $0.5 \mathrm{ml} / \mathrm{min}$. The optical density of two organic acids was measured at $210 \mathrm{~nm}$ with an SPD-20 UV detector (Shimadzu, Japan). To quantify organic acids, the different organic concentrations, which ranged from 1 to $30 \mathrm{mM}$ were used as standards.

\section{Gas chromatography-mass spectrophotometry (GC-MS)}

The metabolites within the CFCS were analyzed using Agilent 7890A Gas chromatograph (Agilent Technology, USA) interfaced to Agilent 5975C (EI) mass-selective detector. The mass spectra were scanned in the mass range of 43 to $550 \mathrm{u}$ at a rate of $0.99 \mathrm{scans} / \mathrm{s}$. Injector, interface and ion source temperatures were held at 260,300 and $230{ }^{\circ} \mathrm{C}$, respectively. A DB-5MS column (30 m x $0.25 \mathrm{~mm}$ I.D., $0.25 \mu \mathrm{m}$ film thickness, Agilent Technology, USA) was used for all analyses. Helium was used as the carrier gas at a constant flow rate of $0.5 \mathrm{~mL} / \mathrm{min}$ for all analyses. The oven temperature was set initially at $100{ }^{\circ} \mathrm{C}(2 \mathrm{~min})$, then increased to $250{ }^{\circ} \mathrm{C}$ at a rate of $5^{\circ} \mathrm{C} / \mathrm{min}$ and finally programmed to $300^{\circ} \mathrm{C}$ at a rate of $20^{\circ} \mathrm{C} / \mathrm{min}(5 \mathrm{~min})$ (modified method from Lee et al., 2012).

\section{Influence of CFCS on Salmonella growth and survival}

$S$. Typhi were pre-cultured in a suitable medium and conditions as previously described. After that, this bacterium was adjusted to obtain the final concentration of approximately at $10^{6}$ $\mathrm{CFU} / \mathrm{ml}$ in LB broth. Then, $S$. Typhi was transferred and cultured in the same medium supplemented with CFCS of WM36 at MIC values in $100 \mathrm{ml}$ Erlenmeyer flask and incubated at $37^{\circ} \mathrm{C}$. The culture broth was sampled at $0,2,4,8,12,16,20$, and $24 \mathrm{~h}$ of incubation. Then each of the samples were serially 10 -fold diluted with $0.85 \%$ normal saline solution (NSS) to obtain the appropriated dilutions. A $0.1 \mathrm{ml}$ of diluted tubes was spread on LB agar (1.5\% agar) plates for Salmonella count. The culture of $S$. Typhi without CFCS served as the control group. All plates were incubated at $37^{\circ} \mathrm{C}$ for $24-48 \mathrm{~h}$ (Shah et al., 2016). The number of viable cells were counted and calculated as the percentage of Salmonella survival with a given formula;

$\%$ Salmonella survival $=($ Viable counts in treatment $/$ Viable counts in control $) \times 100$. 
219 Influence of CFCS on Salmonella motility

$220 S$. Typhi was pre-cultured in LB broth at $37^{\circ} \mathrm{C}$ overnight. Two microliters of the culture were 221 dropped on the center of the LB agar (0.5\% agar) containing the MIC and sub-MICs of CFCS 222 and incubated at $37^{\circ} \mathrm{C}$ for $24 \mathrm{~h}$. Diameter zones of motility were measured (Choi et al., 2012).

223

224

225

226

227

228

229

230

231

232

233

234

235

236

237

238

239

240

241

242

243

244

245

246

247

248

249

250

251

252

253

254

255

256

257

258

259

260

261

262

263

264

\section{Influence of CFCS on Salmonella biofilm formation}

The effect of CFCS against Salmonella biofilm formation was tested on 24-well polystyrene microtiter plates containing a sterile piece of glass $(15 \times 8 \mathrm{~mm})$. CFCS at MIC and sub-MICs were added in LB broth containing the bacterial suspension at $10^{6} \mathrm{CFU} / \mathrm{mL}$. The plates were incubated statically at $37^{\circ} \mathrm{C}$ for $48 \mathrm{~h}$. After incubation, the glass piece was stained with $0.4 \%$ crystal violet solution, washed three times with sterile distilled water and air-dried at room temperature under biosafety cabinet Class 2 . Stained glass was placed on slides with the biofilm in an upright position, and investigated by stereomicroscope (Stemi 508, Zeiss, Germany) at magnifications of x10. Visible biofilms were captured with an attached digital camera (Axiocam 105 color, Zeiss, Germany) and analyzed through the ZEN 2 software program. Negative control wells which contain only LB were added in each assay, while suspension of $S$. Typhi in LB broth was included as a positive control to determine the bacterial adherence and biofilm formation without CFCS (Jeong et al., 2018; Kang et al., 2006; Taheur et al., 2016).

\section{Influence of CFCS on Salmonella virulence gene expression}

$S$. Typhi was cultured in LB broth supplemented with CFCS at MIC and sub-MICs. Bacterial cells were harvested and washed three times with NSS by centrifugation at $6,000 \mathrm{rpm}$, for $15 \mathrm{~min}$ at $4{ }^{\circ} \mathrm{C}$. Bacterial total RNA was extracted using Trizol ${ }^{\circledR}$ reagent (Invitrogen, USA) according to the manufacturer's instructions with slight modification. Briefly, $1 \mathrm{ml}$ of Trizol® reagent was added and incubated for $5 \mathrm{~min}$ to dissociate of nucleoprotein complexes, followed by $0.2 \mathrm{ml}$ of chloroform and incubated for $3 \mathrm{~min}$. The mixture was centrifuged for $15 \mathrm{~min}$ at 12,000x $\mathrm{g}$ at 4 ${ }^{\circ} \mathrm{C}$. An aqueous phase containing RNA was transferred to a new tube and reacted with $0.5 \mathrm{ml}$ of isopropanol, followed by incubating at $4{ }^{\circ} \mathrm{C}$ overnight. After incubation, the mixture was centrifuged at $12,000 \mathrm{x} \mathrm{g}$, for $10 \mathrm{~min}$ at $4{ }^{\circ} \mathrm{C}$. After that, the supernatant was discarded by carefully pouring; the white gel forming pellets containing RNA appeared at the bottom of the tube. A pellet was suspended with $0.5 \mathrm{ml}$ of $75 \%$ ethanol and centrifuged at 7,500g, for $5 \mathrm{~min}$ at $4{ }^{\circ} \mathrm{C}$. The supernatant was discarded; RNA was air-dried for $15 \mathrm{~min}$, suspended in $50 \mu 1$ with nuclease-free water, heated with heat block at $60{ }^{\circ} \mathrm{C}$ for $15 \mathrm{~min}$ and kept at $-20^{\circ} \mathrm{C}$.

After RNA extraction, the total RNA was quantified by Qubit ${ }^{\circledR}$ RNA BR assay kit (Life Technologies, USA) with Qubit ${ }^{\circledR} 3.0$ Fluorometer following the manufacturer's instruction. Then, cDNA was synthesized with a High-Capacity cDNA Reverse Transcription kit (Applied Biosystem, USA) according to the manufacturer's instruction. Briefly, $20 \mu 1$ of reaction consists of $10 \mu \mathrm{l}$ of $0.5 \mu \mathrm{g}$ total RNA, $2 \mu \mathrm{l}$ of 10x RT buffer, $0.8 \mu 1$ of $25 \mathrm{x}$ dNTP, $2 \mu 1$ of 10x random primer, $1 \mu \mathrm{l}$ of multiScribe ${ }^{\mathrm{TM}}$ reverse transcriptase, $1 \mu \mathrm{l}$ of RNase inhibitor and $3.2 \mu 1$ of nuclease-free water. The thermal cycler was programmed as $25^{\circ} \mathrm{C}$ for $10 \mathrm{~min}, 37^{\circ} \mathrm{C}$ for $120 \mathrm{~min}$, $85^{\circ} \mathrm{C}$ for $5 \mathrm{~min}$, and $4{ }^{\circ} \mathrm{C}$ until the program was stopped. All cDNA reaction tubes were kept at $20^{\circ} \mathrm{C}$.

The qPCR assay was performed using a QuantStudio 6 Flex Real-Time PCR cycler (Thermo Fisher Scientific, Massachusetts, USA) with the flowing thermal cycle profile: $50{ }^{\circ} \mathrm{C}$ for 2 min and $95^{\circ} \mathrm{C}$ for $2 \mathrm{~min}$ for initial UDG activation; 40 cycles of $95^{\circ} \mathrm{C}$ for $20 \mathrm{sec}$ (denature) and 60 ${ }^{\circ} \mathrm{C}$ for $20 \mathrm{sec}$ (annealing/extension). A melting curve was generated by heating $95^{\circ} \mathrm{C}$ for $20 \mathrm{sec}$,

Peer) reviewing PDF | (2019:10:41941:1:0:NEW 18 Nov 2019) 
265

266

267

268

269

270

271

272

273

274

275

276

277

278

279

280

281

282

283

284

285

286

287

288

289

290

291

292

293

294

295

296

297

298

299

300

301

302

303

304

305

306

$60{ }^{\circ} \mathrm{C}$ for $20 \mathrm{sec}$, and ramping back to $95^{\circ} \mathrm{C}$ in $0.05^{\circ} \mathrm{C}$ increments. The $20 \mu 1$ of reaction mixture contained $2 \mu 1$ of cDNA samples, $10 \mu 1$ of PowerUp ${ }^{\mathrm{TM}}$ SYBR ${ }^{\circledR}$ Green master mix (Applied Biosystem $^{\mathrm{TM}}$, Massachusetts, USA), $0.2 \mu \mathrm{l}$ of each forward and reverse primer (Table 1), and 7.6 $\mu 1$ of nuclease-free water. The levels of virulence gene expression were normalized using $16 \mathrm{~s}$ rDNA as an internal housekeeping gene, and fold change of target genes was calculated by the $\Delta \Delta \mathrm{Ct}$ method. All values derived from $2-\Delta \Delta \mathrm{Ct}$ represent fold changes of samples in abundance relative to the reference sample. The reference samples had the $2^{-\Delta \Delta \mathrm{Ct}}$ value of 1 . The treatment not subjected to CFCS treatment served as the reference sample (Bayoumi \& Griffiths, 2010; Choi et al., 2012; Muyyarikkandy \& Amalaradjou, 2017; Yang et al., 2014).

\section{Statistical analysis}

Statistical analysis was performed using SPSS (version 17.0) of Windows statistics software (SPSS Inc, Chicago, IL, USA). The data were subjected to analysis of variance followed by Tukey's range test. A difference was considered statistically significant at a $p$-value of less than 0.05 .

\section{Results}

\section{Antibacterial susceptibility tests of CFCS}

To evaluate the antagonistic activity of CFCS of $W$. confusa WM36 on $S$. Typhi, the antibacterial susceptibility test through agar well diffusion and the MIC test were performed. The CFCS of $W$. confusa WM36 showed an inhibitory effect against representative $S$. Typhi with the average inhibitory zone (including $5 \mathrm{~mm}$ diameter of well) as $8.17 \pm 0.29 \mathrm{~mm}$ using the agar well diffusion method. The average CFCS inhibitory zone is lower than the positive control $(5 \mathrm{mg} / \mathrm{ml}$ ampicillin) that yielded an average activity of $12.75 \pm 0.75 \mathrm{~mm}$. The MIC value is $40.00 \%(\mathrm{v} / \mathrm{v})$ and completely inhibited the visible growth in tested wells.

\section{Characterization of antimicrobial substances in CFCS}

From the results, acid-neutralizing CFCS showed no inhibitory clear zone in the vicinity of observed wells when compared to protein-neutralizing, catalase-neutralizing, and untreated CFCS (Figure S1). This indicated that the organic acids are the main antimicrobial substances found in WM36-CFCS. However, WM36-CFCS may have other antimicrobial metabolites in addition to organic acids, which require further investigation.

\section{pH, titratable acidity (TA) and organic acid analysis using the HPLC technique}

The values of $\mathrm{pH}$ and TA (\%lactic acid equivalent; LAE) of CFCS are shown in Table 2 and Table S1. The property of WM36-CFCS was low $\mathrm{pH}$. This property is assumed to be the main anti-salmonella substances are acids. $W$. confusa WM36 can produce lactic acid and acetic acid up to $266 \mathrm{mM}(24.02 \mathrm{~g} / \mathrm{L})$ and $261 \mathrm{mM}(15.96 \mathrm{~g} / \mathrm{L})$, respectively in CFCS (Table 2). The chromatogram of organic acids in standard solution and the WM36 sample are shown in Figure S2. 


\section{Identification of metabolites in CFCS by GC-MS analysis}

WM36 metabolites were identified and are listed in Table 3. The results collected from GC-MS analysis (Table $3 \&$ Dataset 1) revealed that 2,4 DTBP (No. 1) showed the most abundance. This metabolite showed the retention time at 13.450 min with the highest \% peak area of 59.24 . In addition, the other metabolites are also represented in this CFCS, but they showed lower abundance than No.1 compound.

\section{Influence of CFCS on Salmonella growth and survival}

To study the effect of CFCS on Salmonella growth and survival, the MIC of WM36-CFCS was chosen as the most effective inhibition concentration. As shown in Table 4, there was no significant difference in the Salmonella population between the control and treatment at the starting time $(\mathrm{t}=0)$. Significant differences were observed at longer incubation times (at $2-24$ h) due to the effect of WM36-CFCS on the growth of $S$. Typhi in the treatment (Table 4 and Table S2). Salmonella in the control significantly increased from $1.56 \times 10^{6}$ to $8.95 \times 10^{7} \mathrm{CFU} / \mathrm{ml}$ in $4 \mathrm{~h}$ until the end of cultivation at $24 \mathrm{~h}\left(3.12 \times 10^{8} \mathrm{CFU} / \mathrm{ml}\right)$. In contrast, the treatment of $S$. Typhi with CFCS at MIC showed a remarkable decrease of this pathogen from $2.07 \times 10^{6}$ to $5.21 \times 10^{5}$ and $3.47 \times 10^{3} \mathrm{CFU} / \mathrm{ml}$ in 2 and $20 \mathrm{~h}$ of incubation. The results between the control and treatment indicate that CFCS at MIC significantly decreased the pathogen by starting within $2 \mathrm{~h}$ of the incubation test. In the period of time from 4 to $20 \mathrm{~h}$, the MIC of CFCS caused $<1 \%$ survival in the pathogenic population compared with the starting time $(0 \mathrm{~h})$.

\section{Influence of CFCS on Salmonella motility}

Table 5 and Table S3 show the swarming zone of $S$. Typhi in the presence of different concentrations of CFCS at sub-MICs and MIC values. The swarming motility of $S$. Typhi at $10 \%$ $(\mathrm{v} / \mathrm{v})$ (Figure 1b) concentration gave similar results to the control (Figure 1a) with no significant differences $(p>0.05)$. At 20\% (v/v) (Figure 1c) and MIC (Figure 1d), were very effective concentrations, which completely reduced the swarming motility of $S$. Typhi; and there were significant differences $(p<0.05)$ compared with the control.

\section{Influence of CFCS on Salmonella biofilm formation}

The results of the stereomicroscopic analysis for a positive control slide showed a welldeveloped biofilm maturation as shown in Figure 2a, 2b, and 2c, these sub-MICs (10-20 \% (v/v) showed no loose biofilm architecture. Only MIC of WM36 was clearly the most effective concentration for biofilm inhibition of $S$. Typhi indicators (Figure 2d), compared to the negative control slide as shown in Figure 2e.

\section{Influence of CFCS on virulence gene expression}

In this study, virulence gene expressions, including genes responsible for T3SS, effector proteins, and QS-related genes were investigated. The different inhibitory concentrations of CFCS directly affected the significant level of virulence gene expressions with different patterns 
347 as shown in Table 6 . Hence, the down-regulation of these genes could reduce virulence

348

349

350

351

352

353

354

355

356

357

358

359

360

361

362

363

364

365

366

367

368

369

370

371

372

373

374

375

376

377

378

379

380

381

382

383

384

385

386

\section{behaviors of Salmonella.}

Examined genes that are responsible for T3SS and apparatus include hilD, $\operatorname{sop} B$, SopE2, $\operatorname{sip} A, \operatorname{sip} C, \operatorname{invF}$, and $\operatorname{spt} P$. When reacted to various doses of WM36-CFCS, it was found that all tested doses did the down-regulation with significant difference $(p<0.05)$ when compared with the control, except only hilA showed a slight down-regulation as no significant difference ( $p>$ $0.05)$. The $s d i A$ gene performed to be significantly down-regulated $(p<0.05)$ in its expression when reacted to sub-MICs and MIC of WM36-CFCS by comparing with the control, but luxS was only down-regulated at MIC, and there was no significant difference (Table 6). The above results indicate that each SPI-1 and effector proteins, and QS-related genes may decrease in their expressions after exposure with CFCS, the expression of these genes could be further reduced if reacted to higher concentrations of CFCS.

\section{Discussion}

The anti-salmonella activity of WM36-CFCS may be due to various antimicrobial compounds, which are secreted into culture supernatants, such as organic acids, $\mathrm{H}_{2} \mathrm{O}_{2}$, bacteriocins, and possibly others. These compounds are usually the primary and secondary metabolites and act as natural preservatives against spoilage microorganisms in fermented foods (Castellano et al., 2017). $W$. confusa is classified as heterofermentative LAB, which produces lactic acid, acetic acid, and $\mathrm{CO}_{2}$ as the end metabolites after consuming sugars because of its biochemically metabolic pathways (Björkroth, Dicks \& Endo, 2014).

Our CFCS showed lower inhibitory activity against Salmonella than other Weissella isolates, W. confusa Cys2-2 gave the highest inhibitory zone up to $17.66 \mathrm{~mm}$ and $14.00 \mathrm{~mm}$ against Salmonella enterica UTNSm2 and S. Abaetetuba ATCC 35640, respectively. The inhibitory action is due to the presence of antimicrobial peptides, along with organic acids and inhibitory activity, which was also greater when using the agar well diffusion method (Tenea \& Lara, 2019). From the obtained results, it is possible that WM36-CFCS had limited solubility in the agar medium due to the different methodological approach, and it may also depend on the pathogenic virulence of the target organism. These factors made our CFCS show lower activity than reported above. This led us to explore the antimicrobial metabolites produced by $W$. confusa WM36.

To characterize the antimicrobial substances presented in the CFCS, acid-neutralizing CFCS showed on inhibitory activity when compared to other treated CFCS. This indicated that organic acids are the nature of antimicrobial substance presented in WM36-CFCS. This concurs with previous studies by several authors, where organic acids in LAB, including WM36-CFCS, may exert antimicrobial activity versus various serotypes of Salmonella growth (Beier et al., 2017; Koyuncu et al., 2013; Mani-Lopez, García \& López-Malo, 2012; Van Immerseel et al., 2006).

W. confusa WM36 produced lactic acid and acetic acid up to $266 \mathrm{mM}(2.6 \% \mathrm{w} / \mathrm{v})$ and 261 $\mathrm{mM}(1.6 \% \mathrm{w} / \mathrm{v})$, respectively (Table 2$)$. These findings indicate that this strain produced both organic acid higher than other $W$. confusa isolates when compared with previous works (Akanji 
387

388

389

390

391

392

393

394

395

396

397

398

399

400

401

402

403

404

405

406

407

408

409

410

411

412

413

414

415

416

417

418

419

420

421

422

423

424

425

426

\& Alake, 2016; Baek et al., 2012; Musaki et al., 2017). The amount of lactic and acetic acid produced from Weissella confusa was measured in MRS broth and under the experiment performed in this work and was quite similar to the report of Akanji \& Alake, (2016) with the same culture condition that $W$. confusa FS027 from cabbage producing $20,480 \mu \mathrm{g} / \mathrm{ml}(2.04 \%$ $\mathrm{w} / \mathrm{v})$ and $17,184 \mu \mathrm{g} / \mathrm{ml}(1.72 \% \mathrm{w} / \mathrm{v})$ of lactic and acetic acid, respectively. In contrast, the lactic and acetic acid were measured at approximately $2 \mathrm{~g} / \mathrm{kg}(0.2 \% \mathrm{w} / \mathrm{w})$ and $0.1 \mathrm{~g} / \mathrm{kg}(0.01 \% \mathrm{w} / \mathrm{w})$, respectively in $W$. confusa cultured in some cereals (Mukisa et al., 2017). W. confusa D2-96 produced lactic acid and acetic acid from rice cake up to $60.3 \mathrm{mM}(0.54 \% \mathrm{w} / \mathrm{v})$ and $41.6 \mathrm{mM}$ $(0.25 \% \mathrm{w} / \mathrm{v})$ and exerts antifungal activity against spoilage fungi (Baek et al., 2012). In addition to lactic acid and acetic acid, other anti-salmonella might be produced by the WM36 strain as previously mentioned. However, this step can conclude that organic acids produced from WM36, have an important role in inhibiting growth. In order to evaluate whether organic acids in WM36-CFCS are responsible for the inhibitory activity against Salmonella indicator.

Beside lactic acid and acetic acid, 2,4 DTBP is also an important metabolite of WM36CFCS, showing anti-growth activity against $S$. Typhi. 2,4 DTBP is a volatile organic acid compound, is grouped as a member of the phenol class, and plays the main role in antimicrobial and antioxidant activities (Varsha et al., 2015). 2,4 DTBP was found to be a microbial metabolite such as Streptomyces sp., Streptomyces mutabilis, Bacillus licheniformis, Bacillus subtilis,

Pseudomonas monteilii, and Lactococcus sp. (Varsha et al., 2015; Dharni et al., 2014; Chawawisit et al., 2015; Belghit et al., 2016; Viszwapriya et al., 2016; Aissaoui et al., 2018).

This compound shows the bactericidal agent to inhibit the growth of pathogenic bacteria, such as methicillin-resistant Staphylococcus aureus, group A streptococci and Pseudomonas aeruginosa. 2,4 DTBP has fungicidal activity against Aspergillus niger, A. carbonarius, Fusarium oxysporum, Penicillium chrysogenum, Candida albicans and other pathogenic fungi (Varsha et al., 2015; Dharni et al., 2014; Chawawisit et al., 2015; Belghit et al., 2016; Viszwapriya et al., 2016; Aissaoui et al., 2018).

Additionally, 2,4 DTBP has also been recognized as an anti-biofilm agent to reduce the biofilm formation of Serratia marcescens and Streptococcus pyogenes (Viszwapriya et al., 2016). However, 2,4 DTBP has a limitation as it is soluble in water, with an optimum solubility of $35 \mathrm{mg} / \mathrm{L}$ at $25^{\circ} \mathrm{C}$ (NCBI, 2019). It is a possible reason why our CFCS had a limited solubility in the agar well diffusion test and gave the lower anti-salmonella activity by this method.

The mode of action of phenols and phenolic derivatives on microorganisms are to penetrate through cell membranes and inactivate the intracellular enzymes by forming an unstable complex, to inhibit permeases that cause protein denaturation and cell membrane lysis leading to the release of nucleic acid (McDonnell \& Russell, 1999). The phenolic compounds have been reported to show a broad spectrum of biological functions, including antimicrobial, antioxidative and anti-tumor activity. Furthermore, the compound is stable and tolerates any stress conditions. It is usually used as a disinfectant. To the best of our knowledge, this is the first report to find that $W$. confusa can produce 2,4 DTBP, and this compound may act together with organic acids to antagonize the growth of $S$. Typhi. 
427

428

429

430

431

432

433

434

435

436

437

438

439

440

441

442

443

444

445

446

447

448

449

450

451

452

453

454

455

456

457

458

459

460

461

462

463

464

465

The results obtained from the effect of CFCS on Salmonella growth and survival reveal that WM36-CFCS has the potential for controlling $S$. Typhi so it would be possible to use an alternative therapy to control Salmonella. These results also show the reduction of Salmonella growth and population closely correlates with the metabolites and the inhibitory concentration of WM36-CFCS (Tables 2-4). This confirms that organic acids (lactic acid and acetic acid) including 2,4 DTBP are the main metabolites to act as anti-salmonella activity of $W$. confusa WM36.

In order to investigate the effects of different concentrations of WM36-CFCS on Salmonella motility, the swarming motility zone of Salmonella indicator depended on the concentration of CFCS (Figure 1). The CFCS concentrations at 20\% (v/v) and MIC completely reduced Salmonella motility and are more effective than 10\%. However, WM36-CFCS was less effective than the previous reports based on the concentration used the tested volume (Muyyarikkandy \& Amalaradjou, 2017). Only 7.5\% (v/v) of CFCS from Lactobacillus delbreuckii subspecies bulgaricus and L. paracasei reduced $S$. Typhimurium motility up to $\sim 25 \%$ and $\sim 15 \%$. Similarly, the use of L. rhamnosus CFCS with a concentration at $7.5 \%(\mathrm{v} / \mathrm{v})$ resulted in a reduction of three Salmonella serovars (Enteriditis, Typhimurium, and Heidelberg), with motility increased to 40\%, $30 \%$, and 20\%, respectively (Muyyarikkandy \& Amalaradjou, 2017). However, the pathogenic virulence strains should be considered as well.

Biofilms are one of the virulence factors involved in the pathogenesis of $S$. Typhi. This virulence aids Salmonella to survive within stress environments and to resist antibiotics by increasing the efflux pump and enhancing exopolysaccharide production (Peng, 2016). Several LAB and their metabolites were investigated for their ability to inhibit the biofilm formation, and to decrease the number of antibiotic-resistant, biofilm-producing pathogens. For example, Lactobacillus rhamnosus GG can produce lectin-like molecules, namely Llp1 and Llp2 to interfere with the biofilm formation of $S$. Typhimurium. These proteins are involved in the adhesion capacity of L. rhamnosus GG to gastrointestinal epithelium (Petrova et al., 2016). Moreover, some organic acids are an efficient bioactive compound which interfere with the biofilm formation of $S$. Typhimurium; they yield the maximum biofilm inhibition ranging from $13 \%$ to $39 \%$ and also play the main role to inhibit the exopolysaccharide production (the main composition of biofilm) (Amrutha et al., 2017). In this study, WM36-CFCS at MIC showed a reduction of biofilm formation. The findings strongly suggest that our Weissella and its metabolites such as organic acid and 2,4 DTBP may be a new strategy to fight biofilm-producing Salmonella and other pathogens.

The invasion of host epithelial cells is mediated by T3SS, which require a set of genes within SPI-1. The examined genes including hilA, hilD, $\operatorname{sip} A, \operatorname{sip} C, \operatorname{invF}$, and $\operatorname{spt} P$ are located in SPI-1 and play the main role in cell invasion of Salmonella. The expressions of these genes have required the regulation of different regulators, while hilA gene plays the main regulator (Valdez, Ferreira \& Finley, 2019). hilA gene appears to directly activate the $i n v F$ signaling cascade resulting in the expression of effector genes, $\operatorname{sop} B$, and $\operatorname{sopE2}$, which are located in SPI-5. All 
466 the above genes are manipulated and work together as a signaling network to form syringe

467

468

469

470

471

472

473

474

475

476

477

478

479

480

481

482

483

484

485

486

487

488

489

490

491

492

493

494

495

496

497

498

499

500

501

502

503

504 machinery and deliver effector proteins to destruct host cell cytoskeleton (Marcus et al., 2000).

Several LAB and their metabolites can reduce the expression of SPI-1 and related genes. Our work is consistent with cited reports, which have been reported by other authors. For example, the neutralized cell-free supernatants of 4 probiotics including $L$. acidophilus, $L$. plantarum, B. bifidum and B. infantis down-regulate the reporter gene expression of hilA of $S$. Typhimurium when CFCS was added at 50\% (v/v) (Bayoumi \& Griffiths, 2010). Lactobacillus zeae culture fluid also down-regulate the expression of virulence genes responsible for T3SS and effector proteins ( hilA, hilD, sopB, sopE2, sipA, and sptP) of $S$. Typhimurium in vitro (Yang et al., 2014). L. delbreuckii NRRL B548, L. rhamnosus NRRL B442 and L. paracasei DUP-13076 culture supernatants at $7.5 \%(\mathrm{v} / \mathrm{v})$ concentrations also down-regulated the expression of hilA, hilD, sipA and sopB of $S$. Enteritidis, $S$. Heidelberg and $S$. Typhimurium (Muyyarikkandy \& Amalaradjou, 2017). While further research is encouraged, this is the first report that $W$. confusa can reduce the expression of SPI-1 and effector genes of $S$. Typhi. This suggests that WM36CFCS has a greater potential to reduce the virulence of $S$. Typhi.

Numerous bacteria regulate gene expression in the response of changes in their population density through the process called the QS signaling system. QS systems are associated with bacterial pathogenesis (Rutherford \& Bassler, 2012). Bacteria are able to produce, release and detect small signaling molecules termed as autoinducer (AI), which mediate bacterial communications. Salmonella enterica has at least 3 types of AI signaling systems; the AI1/LuxIR system, the AI-2/LuxS system, and the AI-3 system (Parker \& Sperandio, 2009; Walters \& Sperandio, 2006).

The AI-1/LuxIR system is usually found in Gram-negative bacteria; these bacteria consist of LuxI synthase, which plays a role in producing acyl-homoserine lactones (AHLs) as AI-1 molecules (Miller \& Bassler, 2001). AHL is recognized by the LuxR receptor, which is encoded by the luxR gene, while the LuxI synthase is encoded by the luxI gene. After binding, the signaling cascades are activated and subsequently, several genes are expressed (Parker \& Sperandio, 2009; Sifri, 2008). Salmonella does not produce AHL due to the lack of the luxI gene, but can detect AHLs by SdiA, the LuxR homology (Ahmer et al., 1998; Dyszel et al., 2010; Sperandio, 2010). AI-1/LuxIR of Salmonella is necessary to regulate the expression of several genes in virulence plasmid, especially the rck gene, which aids Salmonella to resist the host immune defense (Ahmer et al., 1998; Soares \& Ahmer, 2011).

The AI-2/LuxS system has also been found to be a universal QS system in both Gramnegative and Gram-positive bacteria, and mediates inter-species specific communication. AI-2 molecules are produced by the LuxS enzymes, which are encoded by the luxS gene, then released into environments through membrane transporter proteins. Extracellular AI-2 can bind the autoinducer binding protein LsrB on the bacterial cell surface, and are transported into the cell cytoplasm via the Lsr apparatus, then the signal cascades are activated (Federle, 2009; Pereira, Thompson \& Xavier, 2013; Pui et al., 2011). The AI-2/LuxS system is important for Salmonella 
505 invasion; this system is activated by the expression of SPI-1 proteins which are responsible for

506

507

508

509

510

511

512

513

514

515

516

517

518

519

520

521

522

523

524

525

526

527

528

529

530

531

532

533

534

535

536

537

538

539

540

542

543

\section{1 \\ 41 Acknowledgements}

\section{T3SS formation (Choi, Shin \& Ryu, 2007).}

In the case of the AI-3 system, signaling molecules are accomplished by a two-component system, comprised of histidine sensor kinase QseC and the response regulator QseB. The AI-3 production and structure are still unclear. QseC undergoes autophosphorylation and transfers a phosphate group to QseB, which activates a gene responsible for flagella biosynthesis and motility (Parker \& Sperandio, 2009). In addition, the QseB regulator of the host's normal flora is also recognized for epinephrine, norepinephrine and neurotransmitter. This system induces the SPI-2 gene expression to support Salmonella survival in macrophage, as well as facilitates the expression of gene encoded on SPI-1 and SPI-3 (Bearson \& Bearson, 2008; Gart et al., 2016; Morei, Weinshenker \& Sperandio, 2010)

In this present work, the sdiA and luxS only, were chosen for the QS genes by interfering with the expression of these genes with CFCS. They have clear known signaling pathways, and are associated with the critical induction of SPI genes. The down-regulation of these genes might reduce the expression of signaling cascades that lead to inhibit mechanisms of Salmonella pathogenesis.

The examined virulence genes showed variety in their expressions; the expressions of these genes may down-regulate depending on the concentrations of CFCS. The highest tested concentration gave a highly reduced expression compared to lower concentrations. Hence, CFCS at MIC or $>$ MIC values are the most effective inhibitory concentrations to control the levels of virulence gene expressions.

\section{Conclusions}

This study revealed the anti-S. Typhi activities of $W$. confusa WM36. This LAB isolate was able to produce the antibacterial growth, survival and anti-virulence substances, which were characterized as major compounds of organic acids (mainly lactic acid and acetic acid) and 2,4 DTBP. WM36-CFCS at MIC reduced the number of $S$. Typhi populations of more than $99.99 \%$. The sub-MIC and MIC of WM36-CFCS showed the inhibitory patterns on motility, biofilm formation, and virulence gene expression of Salmonella indicator, the reduction of these virulence behaviors indicating a significant decrease in virulence ability on bacterial pathogenesis of typhoid/MDR-Salmonella. Therefore, $W$. confusa WM36 and/or its metabolites could be potentially used as alternative therapies for controlling the Salmonella infection and/or use alongside with a usual treatment. However, the efficacy and safety evaluation of $W$. confusa WM36 and efficacy of each purify metabolite in vitro and in vivo have no adequate supporting information. These findings will be corroborated in the future research.

We thank all the members in our academic group for helping us complete the experiments. This research work was partially supported by Chiang Mai University. The authors also acknowledge 
544 the Faculty of Pharmacy, Chiang Mai University, Chiang Mai, Thailand for kind assistance in

545 allowing us to conduct the research work.

546

547 References

548 Ahmer BM, Van Reeuwijk J, Timmers CD, Valentine PJ, Heffron F. 1998. Salmonella

549

550

551

552

553

554

555

556

557

558

559

560

561

562

563

564

565

566

567

568

569

570

571

572

573

574

575

576

577

578

579

580

581

582

583 typhimurium encodes an SdiA homolog, a putative quorum sensor of the LuxR family, that regulates genes on the virulence plasmid. Journal of Bacteriology 180(5): 1185-1193.

Aissaoui N, Mahjoubi M, Nas F, Mghirbi O, Arab M, Souissi Y, Hoceini A, Masmoudi AS, Mosbah A, Cherif A, Klouche-Khelil N. 2018. Antibacterial potential of 2, 4-Di-tertbutylphenol and calixarene-based prodrugs from thermophilic Bacillus licheniformis isolated in Algerian hot spring. Geomicrobiology Journal 36(1): 1-10 DOI

10.1080/01490451.2018.1503377.

Akanji BT, Alake AB. 2016. Evaluation of organic acids, anti-salmonella activities of lactic acid bacteria isolated from Nigerian grown salad vegetables. Biotechnology Journal International 11(1), 1-10 DOI 10.9734/BBJ/2016/22551.

Amrutha B, Sundar K, Shetty PH. 2017. Effect of organic acids on biofilm formation and quorum signaling of pathogens from fresh fruits and vegetables. Microbial Pathogenesis 111: 156-162 DOI 10.1016/j.micpath.2017.08.042.

Baek E, Kim H, Choi H, Yoon S, Kim J. 2012. Antifungal activity of Leuconostoc citreum and Weissella confusa in rice cakes. Journal of Microbiology 50(5): 842-848 DOI 10.1007/s12275-012-2153-y.

Bayoumi MA, Griffiths MW. 2010. Probiotics down-regulate genes in Salmonella enterica serovar Typhimurium pathogenicity islands 1 and 2. Journal of Food Protection 73(3): 452460 DOI 10.4315/0362-028x-73.3.452.

Bearson BL, Bearson SM. 2008. The role of the QseC quorum-sensing sensor kinase in colonization and norepinephrine-enhanced motility of Salmonella enterica serovar Typhimurium. Microbial Pathogenesis 44(4): 271-278 DOI 10.1016/j.micpath.2007.10.001.

Beier RC, Callaway TR, Andrews K, Poole TL, Crippen TL, Anderson RC, Nisbet DJ. 2017. Interactions of organic acids with Salmonella strains from feedlot water-sprinkled cattle. Journal of Food Chemistry and Nanotechnology 3(2): 60-66 DOI 10.17756/jfcn.2017-03.

Belghit S, Driche EH, Bijani C, Zitouni A, Sabaou N, Badji B, Mathieu F. 2016. Activity of 2, 4Di-tert-butylphenol produced by a strain of Streptomyces mutabilis isolated from a Saharan soil against Candida albicans and other pathogenic fungi. Journal de Mycologie Medicale 26(2): 160-169 DOI 10.1016/j.mycmed.2016.03.001.

Ben Slama R, Kouidhi B, Zmantar T, Chaieb K, Bakhrouf A. 2013. Anti-listerial and anti-biofilm activities of potential probiotic Lactobacillus strains isolated from Tunisian traditional fermented food. Journal of Food Safety 33(1): 8-16 DOI doi.org/10.1111/jfs. 12017.

Björkroth JA, Dicks LMTD, Endo A. 2014. The genus Weissella. In: Holzapfel WH, Wood BJB, eds. Lactic Acid Bacteria, Biodiversity and Taxonomy. Chichester: Wiley Blackwell, 418-428. 
584 Both E, György É, Ábrahám B, Lányi S. 2011. Beneficial effects of probiotic microorganisms. A

585

586

587

588

589

590

591

592

593

594

595

596

597

598

599

600

601

602

603

604

605

606

607

608

609

610

611

612

613

614

615

616

617

618

619

620

621

622

623 review. Acta Universitatis Sapientiae, Alimentaria 4: 44-58.

Castellano P, Pérez Ibarreche M, Blanco Massani M, Fontana C, Vignolo G. 2017. Strategies for pathogen biocontrol using lactic acid bacteria and their metabolites: a focus on meat ecosystems and industrial environments. Microorganisms 5(3): Article 38 DOI 10.3390/microorganisms5030038.

Chavasirikunton V, Vatanyoopaisarn S, Phalakornkule C. 2006. Bacteriocin-like activity from Weissella confusa and Pediococcus acidilactici isolated from traditional Thai fermented sausages. Journal of Culture Collection 5(1): 64-72.

Chawawisit K, Bhoopong P, Phupong W, Lertcanawanichakul M. 2015. 2, 4-Di-tertbutylphenol, the bioactive compound produced by Streptomyces sp. KB1. Journal of Applied Pharmaceutical Science 5(suppl 3): 7-12 DOI 10.7324/JAPS.2015.510.S2.

Choi J, Shin D, Kim M, Park J, Lim S, Ryu S. 2012. LsrR-mediated quorum sensing controls invasiveness of Salmonella typhimurium by regulating SPI-1 and flagella genes. PloS One 7(5): Article e37059 DOI 10.1371/journal.pone.0037059.

Choi J, Shin D, Ryu S. 2007. Implication of quorum sensing in Salmonella enterica serovar Typhimurium virulence: the $l u x S$ gene is necessary for expression of genes in pathogenicity island 1. Infection and Immunity 75(10), 4885-4890 DOI 10.1128/IAI.01942-06.

de Jong HK, Parry CM, van der Poll T, Wiersinga WJ. 2012. Host-pathogen interaction in invasive salmonellosis. PLoS Pathogen 8(10): Article e1002933 DOI 10.1371/journal.ppat.1002933.

Dharni S, Maurya A, Samad A, Srivastava SK, Sharma A, Patra DD. 2014. Purification, characterization, and in vitro activity of 2, 4-di-tert-butylphenol from Pseudomonas monteilii PsF84: conformational and molecular docking studies. Journal of Agricultural and Food Chemistry 62: 6138-6146 DOI 10.1021/jf5001138.

Dicks LM, Dreyer L, Smith C, Van Staden AD. 2018. A review: the fate of bacteriocins in the human gastro-intestinal tract: do they cross the gut-blood barrier?. Frontiers in Microbiology 9: Article 2297 DOI 10.3389/fmicb.2018.02297.

Dyszel JL, Smith JN, Lucas DE, Soares JA, Swearingen MC, Vross MA, Young GM, Ahmer BM. 2010. Salmonella enterica serovar Typhimurium can detect acyl homoserine lactone production by Yersinia enterocolitica in mice. Journal of Bacteriology 192(1): 29-37 DOI 10.1128/JB.01139-09.

Eng SK, Pusparajah P, Ab Mutalib NS, Ser HL, Chan KG, Lee LH. 2015. Salmonella: a review on pathogenesis, epidemiology and antibiotic resistance. Frontiers in Life Science 8(3): 284293 DOI 10.1080/21553769.2015.1051243.

Federle MJ. 2009. Autoinducer-2-based chemical communication in bacteria: complexities of interspecies signaling. In: Collin M, Schuch R, eds. Bacterial Sensing and Signaling. Basel: Karger Publishers, 18-32.

Fessard A, Remize F. 2017. Why are Weissella spp. not used as commercial starter cultures for food fermentation?. Fermentation 3(3): Article 38 DOI 10.3390/fermentation3030038. 
624 Fusco V, Quero GM, Cho GS, Kabisch J, Meske D, Neve H, Bockelmann W, Franz CMAP.

625

626

627

628

629

630

631

632

633

634

635

636

637

638

639

640

641

642

643

644

645

646

647

648

649

650

651

652

653

654

655

656

657

658

659

660

661

662

663

2015. The genus Weissella: taxonomy, ecology and biotechnological potential. Frontiers in Microbiology 6: Article 155 DOI 10.3389/fmicb.2015.00155.

Gart EV, Suchodolski JS, Welsh JrTH, Alaniz RC, Randel RD, Lawhon SD. 2016. Salmonella

Typhimurium and multidirectional communication in the gut. Frontiers in Microbiology 7 : Article 1827 DOI 10.3389/fmicb.2016.01827.

Jeong D, Kim DH, Song KY, Seo KH. 2018. Antimicrobial and anti-biofilm activities of Lactobacillus kefiranofaciens DD2 against oral pathogens. Journal of Oral Microbiology 10(1): Article 1472985 DOI 10.1080/20002297.2018.1472985.

John J, Van Aart CJC, Grassly NC. 2016. The burden of typhoid and paratyphoid in India: systematic review and meta-analysis. PLOS Neglected Tropical Diseases 10(4): Article e0004616 DOI 10.1371/journal.pntd.0004616.

Kang MS, Chung J, Kim SM, Yang KH, Oh JS. 2006. Effect of Weissella cibaria isolates on the formation of Streptococcus mutans biofilm. Caries Research 40(5): 418-425 DOI $10.1159 / 000094288$.

Kaur J, Jain SK. 2012. Role of antigens and virulence factors of Salmonella enterica serovar Typhi in its pathogenesis. Microbiological Research 167(4): 199-210 DOI 10.1016/j.micres.2011.08.001.

Koyuncu S, Andersson MG, Löfström C, Skandamis PN, Gounadaki A, Zentek J, Häggblom P. 2013. Organic acids for control of Salmonella in different feed materials. BMC Veterinary Research 9(1): Article 81 DOI 10.1186/1746-6148-9-81.

Lee JY, Nguyen DT, Park YS, Hwang KY, Cho YS, Kang KD, Yoon JH, Yu JD, Yee ST, Ahn YH, Lee G. 2012. Organic acid profiling analysis in culture media of lactic acid bacteria by gas chromatography-mass spectrometry. Mass Spectrometry Letters 3(3): 74-77 DOI 10.5478/MSL.2012.3.3.74.

Lee, Y.H. 2004. Weissella confusa strain PL9001 inhibits growth and adherence of genitourinary pathogens. Journal of Microbiology and Biotechnology 14(4): 680-685.

Lin WH, Wu CR, Fang TJ, Guo JT, Huang SY, Lee MS, Yang HL. 2011. Anti-Helicobacter pylori activity of fermented milk with lactic acid bacteria. Journal of The Science of Food and Agriculture 91(8); 1424-1431 DOI 10.1002/jsfa.4327.

Mani-Lopez E, García HS, López-Malo A. 2012. Organic acids as antimicrobials to control Salmonella in meat and poultry products. Food Research International 45(2): 713-721 DOI 10.1016/j.foodres.2011.04.043.

Marcus SL, Brumell JH, Pfeifer CG, Finlay BB. 2000. Salmonella pathogenicity islands: big virulence in small packages. Microbes and Infection 2(2): 145-156 DOI 10.1016/S12864579(00)00273-2.

McDonnell G, Russell AD. 1999. Antiseptics and disinfectants: activity, action, and resistance. Clinical Microbiology Reviews 12(1): 147-149.

Miller MB, Bassler BL. 2001. Quorum sensing in bacteria. Annual Review of Microbiology 55(1): 165-199 DOI 10.1146/annurev.micro.55.1.165.

Peer) reviewing PDF | (2019:10:41941:1:0:NEW 18 Nov 2019) 
664 Moreira CG, Weinshenker D, Sperandio V. 2010. QseC mediates Salmonella enterica serovar

665

666

667

668

669

670

671

672

673

674

675

676

677

678

679

680

681

682

683

684

685

686

687

688

689

690

691

692

693

694

695

696

697

698

699

700

701

702

Typhimurium virulence in vitro and in vivo. Infection and Immunity 78(3): 914-926 DOI 10.1128/IAI.01038-09.

Mukisa IM, Byaruhanga YB, Muyanja CMBK, Langsrud T, Narvhus JA. 2017. Production of organic flavor compounds by dominant lactic acid bacteria and yeasts from Obushera, a traditional sorghum malt fermented beverage. Food Science \& Nutrition 5: 702-712. DOI: $10.1002 /$ fsn3.450.

Mutai WC, Muigai AW, Waiyaki P, Kariuki S. 2018. Multi-drug resistant Salmonella enterica serovar Typhi isolates with reduced susceptibility to ciprofloxacin in Kenya. BMC Microbiology 18(1): Article 187 DOI 10.1186/s12866-018-1332-3.

Muyyarikkandy, M.S.; Amalaradjou, M.A. 2017. Lactobacillus bulgaricus, Lactobacillus rhamnosus and Lactobacillus paracasei attenuate Salmonella Enteritidis, Salmonella Heidelberg and Salmonella Typhimurium colonization and virulence gene expression in vitro. International Journal of Molecular Sciences 18(11): Article 2381 DOI 10.3390/ijms18112381.

Nam H, Ha M, Bae O, Lee Y. 2002. Effect of Weissella confusa strain PL9001 on the adherence and growth of Helicobacter pylori. Applied and Environmental Microbiology 68(9): 46424645 DOI 10.1128/AEM.68.9.4642-4645.200.

National Center for Biotechnology Information (NCBI). 2019. 2,4-Di-tert-butylphenol. Available at https://pubchem.ncbi.nlm.nih.gov/compound/2_4-Di-tert-butylphenol (accessed on 1 August 2019).

Pandey KR, Naik SR, Vakil BV. 2015. Probiotics, prebiotics and synbiotics-a review. Journal of Food Science and Technology 52(12): 7577-7587 DOI 10.1007/s13197-015-1921-1.

Parker CT, Sperandio V. 2009. Cell-to-cell signalling during pathogenesis. Cellular Microbiology 11(3): 363-369 DOI 10.1111/j.1462-5822.2008.01272.x.

Peng, D. 2016. Biofilm formation of Salmonella. In: Dhanasekaran D, Thajuddin N, eds. Microbial biofilms-Importance and Applications. London: IntechOpen, 231-249.

Pereira CS, Thompson JA, Xavier KB. 2013. AI-2-mediated signalling in bacteria. FEMS Microbiology Reviews 37(2): 156-181 DOI 10.1111/j.1574-6976.2012.00345.x.

Pessione E. 2012. Lactic acid bacteria contribution to gut microbiota complexity: lights and shadows. Frontiers in Cellular and Infection Microbiology 2, Article 86 DOI 10.3389/fcimb.2012.00086.

Petrova MI, Imholz NC, Verhoeven TL, Balzarini J, Van Damme EJ, Schols D, Vanderleyden J, Lebeer S. 2016. Lectin-like molecules of Lactobacillus rhamnosus GG inhibit pathogenic Escherichia coli and Salmonella biofilm formation. PLoS One 11(8): Article e0161337 DOI 10.1371/journal.pone.0161337.

Pui CF, Wong WC, Chai LC, Tunung R, Jeyaletchumi P, Noor Hidayah MS, Ubong A, Farinazlenn MG, Cheah YK, Son R. 2011. Salmonella: A foodborne pathogen. International Food Research Journal 473(18): 465-473.

Peer) reviewing PDF | (2019:10:41941:1:0:NEW 18 Nov 2019) 
703

704

705

706

707

708

709

710

711

712

713

714

715

716

717

718

719

720

721

722

723

724

725

726

727

728

729

730

731

732

733

734

735

736

737

738

739

740

741

742

Purkhayastha SD, Bhattacharya MK, Prasad HK, Upadhyaya H, Lala SD, Pal K, Sharma GD. 2017. Antibacterial activity of Weissella confusa isolated from vaginal swab of Indian women. International Journal of Advances in Chemical Engineering and Biological Sciences 4(1): 98-102 DOI 10.15242/ijacebs.a0217021.

Raffatellu M, Wilson RP, Winter SE, Baumler AJ. 2018. Clinical pathogenesis of typhoid fever. The Journal of Infection in Developing Countries 2(4): 260-266 DOI 10.3855/jidc. 219.

Rattanachaikunsopon P, Phumkhachorn P. 2010. Lactic acid bacteria: their antimicrobial compounds and their uses in food production. Annals of Biological Research 1(4): 218-228.

Reis NA, Saraiva MAF, Duarte EAA, Carvalho EA, Vieira BB, Evangelista-Barreto NS. 2016. Probiotic properties of lactic acid bacteria isolated from human milk. Journal of Applied Microbiology 121(3): 811-820 DOI 10.1111/jam.13173.

Rutherford ST, Bassler BL. 2012. Bacterial quorum sensing: its role in virulence and possibilities for its control. Cold Spring Harbor Perspectives in Medicine 2(11): Article a012427 DOI 10.1101/cshperspect.a012427.

Shah N, Patel A, Ambalam P, Holst O, Ljungh A, Prajapati J. 2016. Determination of an antimicrobial activity of Weissella confusa, Lactobacillus fermentum, and Lactobacillus plantarum against clinical pathogenic strains of Escherichia coli and Staphylococcus aureus in co-culture. Annals of Microbiology 66(3): 1137-1143 DOI 10.1007/s13213-016-1201-y. Sifri CD. 2008. Quorum sensing: bacteria talk sense. Clinical Infectious Diseases 47(8), 10701076 DOI 10.1086/592072.

Silva CCG, Silva SPM, Ribeiro SC. 2018. Application of bacteriocins and protective cultures in dairy food preservation. Frontiers in Microbiology 9: Article 594 DOI 10.3389/fmicb.2018.00594.

Soares JA, Ahmer BM. 2011. Detection of acyl-homoserine lactones by Escherichia and Salmonella. Current Opinion in Microbiology 14(2), 188-193 DOI 10.1016/j.mib.2011.01.006.

Sperandio V. 2010. SdiA sensing of acyl-homoserine lactones by enterohemorrhagic $E$. coli (EHEC) serotype O157: H7 in the bovine rumen. Gut Microbes 1(6): 432-435 DOI 10.4161/gmic.1.6.14177.

Šušković J, Kos B, Beganović J, Pavunc AL, Habjanič K, Matošić S. 2010. Antimicrobial activity -the most important property of probiotic and starter lactic acid bacteria. Food Technology and Biotechnology 48(3): 296-307.

Taheur FB, Kouidhi B, Fdhila K, Elabed H, Slama RB, Mahdouani K, Bakhrouf A, Chaieb K. 2016. Anti-bacterial and anti-biofilm activity of probiotic bacteria against oral pathogens. Microbial Pathogenesis 97: 213-220 DOI 10.1016/j.micpath.2016.06.018.

Tenea GN, Lara MI. 2019. Antimicrobial compounds produced by Weissella confusa Cys2-2 strain inhibit Gram-negative bacteria growth. CyTA-Journal of Food 17(1): 105-111 DOI 10.1080/19476337.2018.1561520.

Therdtatha P, Tandumrongpong C, Pilasombut K, Matsusaki H, Keawsompong S, Nitisinprasert S. 2016. Characterization of antimicrobial substance from Lactobacillus salivarius KL-D4 
743

744

745

746

747

748

749

750

751

752

753

754

755

756

757

758

759

760

761

762

763

764

765

766

767

768

769

and its application as biopreservative for creamy filling. Springerplus 5(1): Article 1060 DOI 10.1186/s40064-016-2693-4.

Valdez Y, Ferreira RB, Finlay BB. 2019. Molecular mechanisms of Salmonella virulence and host resistance. In: Sasakawa C, ed. Molecular mechanisms of bacterial infection via the gut. Berlin: Springer, 93-127.

Van Immerseel F, Russell JB, Flythe MD, Gantois I, Timbermont L, Pasmans F, Haesebrouck F, Ducatelle R. 2006. The use of organic acids to combat Salmonella in poultry: a mechanistic explanation of the efficacy. Avian Pathology 35(3): 182-188 DOI 10.1080/03079450600711045.

Varsha KK, Devendra L, Shilpa G, Priya S, Pandey A, Nampoothiri KM. 2015. 2, 4-Di-tert-butyl phenol as the antifungal, antioxidant bioactive purified from a newly isolated Lactococcus sp. International Journal of Food Microbiology 211: 44-50 DOI 10.1016/j.ijfoodmicro.2015.06.025.

Veeraraghavan B, Pragasam AK, Bakthavatchalam YD, Ralph R. 2018. Typhoid fever: issues in laboratory detection, treatment options \& concerns in management in developing countries. Future Science OA 4(6): Article FSO312 DOI 10.4155/fsoa-2018-0003.

Viszwapriya D, Prithika U, Deebika S, Balamurugan K, Pandian SK. 2016. In vitro and in vivo antibiofilm potential of 2, 4-Di-tert-butylphenol from seaweed surface associated bacterium Bacillus subtilis against Group A Streptococcus. Microbiol Research 191: 19-31 DOI 10.1016/j.micres.2016.05.010.

Walters M, Sperandio V. 2006. Quorum sensing in Escherichia coli and Salmonella. International Journal of Medical Microbiology 296(2-3): 125-131 DOI 10.1016/j.ijmm.2006.01.041.

Yang X, Brisbin J, Yu H, Wang Q, Yin F, Zhang Y, Sabour P, Gong J. 2014. Selected lactic acid-producing bacterial isolates with the capacity to reduce Salmonella translocation and virulence gene expression in chickens. PLoS One 9(4): 1-10 DOI 10.1371/journal.pone.0093022.

Peer] reviewing PDF | (2019:10:41941:1:0:NEW 18 Nov 2019) 


\section{Table $\mathbf{1}$ (on next page)}

Lists of forward and reverse primers used in this study 
1 Table 1: Lists of forward and reverse primers used in this study

\begin{tabular}{|c|c|c|c|}
\hline Genes & Primers $\left(5^{\prime}-3^{\prime}\right)$ & $\begin{array}{l}\text { Amplicon } \\
\text { size (bp) }\end{array}$ & References \\
\hline \multicolumn{4}{|c|}{ Housekeeping gene } \\
\hline $16 s r R N A$ & $\begin{array}{l}\text { Forward: CAGAAGAAGCACCGGCTAACTC } \\
\text { Reverse: GCGCTTTACGCCCAGTAATT }\end{array}$ & 87 & Yang et al., 2014 \\
\hline \multicolumn{4}{|c|}{ Virulence genes } \\
\hline hilA & $\begin{array}{l}\text { Forward: CATGGCTGGTCAGTTGGAG } \\
\text { Reverse: CGTAATTCATCGCCTAAACG }\end{array}$ & 150 & Yang et al., 2014 \\
\hline hilD & $\begin{array}{l}\text { Forward: ACTCGAGATACCGACGCAAC } \\
\text { Reverse: CTTCTGGCAGGAAAGTCAGG }\end{array}$ & 129 & Yang et al., 2014 \\
\hline $\operatorname{sop} B$ & $\begin{array}{l}\text { Forward: AACCGTTCTGGGTAAACAAGAC } \\
\text { Reverse: GGTCCGCTTTAACTTTGGCTAAC }\end{array}$ & 77 & Yang et al., 2014 \\
\hline sopE2 & $\begin{array}{l}\text { Forward: GCCTGCATCAACAAACAGACA } \\
\text { Reverse: ATACCGCCCTACCCTCAGAAG }\end{array}$ & 72 & Yang et al., 2014 \\
\hline $\operatorname{sip} A$ & $\begin{array}{l}\text { Forward: GGCTTGCGTGCGGAAATA } \\
\text { Reverse: ATCGCTACATTGCGCTTTCA }\end{array}$ & 69 & Yang et al., 2014 \\
\hline $\operatorname{sip} C$ & $\begin{array}{l}\text { Forward: CTGTGGCTTTCAGTGGTCAG } \\
\text { Reverse: TGCGTTGTCCGGTAGTATTTC }\end{array}$ & 150 & Yang et al., 2014 \\
\hline sptP & $\begin{array}{l}\text { Forward: ATGCTCGTGCCTGGTGGTGTTA } \\
\text { Reverse: ACGGTAACGGCTGGTGATCT }\end{array}$ & 236 & Yang et al., 2014 \\
\hline$i n v F$ & $\begin{array}{l}\text { Forward: GCAGGATTAGTGGACACGAC } \\
\text { Reverse: TTTACGATCTTGCCAAATAGCG }\end{array}$ & 87 & Choi et al., 2012 \\
\hline sdiA & $\begin{array}{l}\text { Forward: AGCAGTTTACGCTGCTCCTC } \\
\text { Reverse: GCCGTCCACTTCAGAATCTC }\end{array}$ & 164 & This study \\
\hline $\operatorname{lux} S$ & $\begin{array}{l}\text { Forward: AGCATCTGTTTGCTGGCTTT } \\
\text { Reverse: TCCTGCACTTTCAGCACATC }\end{array}$ & 178 & This study \\
\hline
\end{tabular}


Table 2 (on next page)

$\mathrm{pH}$, titratable acidity (\% LAE) and organic acids in WM36-CFCS

All values provided as mean \pm standard deviations of triplicate $(*)$ or duplicate $(* *)$. 
1 Table 2: $\mathbf{p H}$, titratable acidity (\% LAE) and organic acids in WM36-CFCS

2 All values provided as mean \pm standard deviations of triplicate $(*)$ or duplicate $(* *)$.

3

\begin{tabular}{cccc}
\hline \multirow{2}{*}{$\mathrm{pH}^{*}$} & \multirow{2}{*}{ \%LAE* } & \multicolumn{2}{c}{ Organic acids $(\mathrm{mM})^{* *}$} \\
\cline { 3 - 4 } & & Lactic acid & Acetic acid \\
\hline $4.53 \pm 0.01$ & $1.10 \pm 0.05$ & $266.70 \pm 0.81$ & $261.33 \pm 7.92$ \\
\hline
\end{tabular}

4 


\section{Table 3 (on next page)}

Metabolites in cell-free culture supernatant of W. confusa WM36 
1 Table 3: Metabolites in cell-free culture supernatant of $W$. confusa WM36

\begin{tabular}{|c|c|c|c|}
\hline Number & Chemical constituents & Area (\%) & Retention time (min) \\
\hline 1 & 2,4-Di-tert-butylphenol & 59.24 & 13.450 \\
\hline 2 & Unknown & 1.89 & 16.107 \\
\hline 3 & Unknown & 0.44 & 17.706 \\
\hline 4 & $1,3,6,10$-dodecatetraene & 1.26 & 18.117 \\
\hline 5 & 3, 5-di-tert-butyl-4-hydroxybenzaldehyde & 0.63 & 19.010 \\
\hline 6 & Myristic acid & 0.34 & 19.126 \\
\hline 7 & Unknown & 0.65 & 19.305 \\
\hline 8 & $\begin{array}{l}\text { 2-propoxyethyl 4-(2, 4- } \\
\text { dimethoxyphenyl)-2-methyl-5-oxo- } 1,4 \text {, } \\
5,6,7,8 \text {-hexahydro-3- } \\
\text { quinolincarboxylate }\end{array}$ & 2.75 & 19.408 \\
\hline 9 & Unknown & 1.05 & 20.080 \\
\hline 10 & Unknown & 0.47 & 20.890 \\
\hline 11 & Phthalic acid & 0.62 & 21.124 \\
\hline 12 & Cyclohexadecane & 0.50 & 21.577 \\
\hline 13 & Unknown & 0.93 & 22.030 \\
\hline 14 & Unknown & 0.90 & 22.359 \\
\hline 15 & Methyl hexadecanoate & 0.59 & 22.448 \\
\hline 16 & $\begin{array}{l}\text { Methyl-3-(3,5-ditertbuthyl-4- } \\
\text { hydroxyphenyl) propionic acid }\end{array}$ & 1.92 & 22.503 \\
\hline 17 & Dibutyl benzene-1,2-dicarboxylic acid & 3.65 & 23.018 \\
\hline 18 & Hexadecanoic acid & 0.37 & 23.196 \\
\hline 19 & Ethyl 9-hexaadecenoate & 0.27 & 23.347 \\
\hline 20 & Unknown & 0.43 & 23.807 \\
\hline 21 & Unknown & 0.29 & 24.342 \\
\hline 22 & Unknown & 0.22 & 25.145 \\
\hline 23 & $p$, $p$ '-diphenylmethane diisocyanate & 0.56 & 25.825 \\
\hline 24 & Oleic acid, ethyl ester & 0.78 & 26.971 \\
\hline 25 & 9-octadecenoic acid (z)-, ethyl ester & 0.48 & 27.088 \\
\hline 26 & Tetracosane & 0.28 & 30.945 \\
\hline 27 & Pentacosane & 0.74 & 32.482 \\
\hline 28 & $\begin{array}{l}\text { 1, 2-benzenedicarboxylic acid, mono (2- } \\
\text { ethylhexyl) ester }\end{array}$ & 0.36 & 32.832 \\
\hline 29 & Docosane & 1.50 & 33.553 \\
\hline 30 & Heptacosane & 1.88 & 34.342 \\
\hline 31 & Eicosane & 1.75 & 35.029 \\
\hline 32 & Unknown & 0.27 & 35.111 \\
\hline 33 & Nonacosane & 1.66 & 35.749 \\
\hline 34 & Unknown & 0.53 & 36.051 \\
\hline 35 & Unknown & 0.18 & 36.182 \\
\hline 36 & Unknown & 1.37 & 36.539 \\
\hline 37 & Unknown & 1.21 & 37.424 \\
\hline 38 & Unknown & 0.99 & 38.467 \\
\hline
\end{tabular}




\section{Table 4 (on next page)}

Effect of WM36-CFCS at MIC (40\%) on viable cells of Salmonella Typhi

All values provide as mean \pm standard deviation of triplicate, the asterisk $(*)$ indicates the significant difference $(p<0.05)$ between the treatment and control. The lowercase letters for control and treatment in each column, and uppercase letters for \% survival, which connected by the different letters are significantly different $(p<0.05)$. 


\section{Table 4: Effect of WM36-CFCS at MIC (40\%) on viable cells of Salmonella Typhi}

2 All values provide as mean \pm standard deviation of triplicate, the asterisk $(*)$ indicates the 3 significant difference $(p<0.05)$ between the treatment and control. The lowercase letters for 4 control and treatment in each column, and uppercase letters for \% survival, which connected by 5 the different letters are significantly different $(p<0.05)$.

6

\begin{tabular}{|c|c|c|c|}
\hline \multirow[t]{2}{*}{ Time (h) } & \multicolumn{2}{|c|}{ Salmonella populations (CFU/ml) } & \multirow[t]{2}{*}{ Salmonella survival(\%) } \\
\hline & Control & With CFCS & \\
\hline 0 & $1.56 \times 10^{6} \pm 1.25 \times 10^{5} \mathrm{a}$ & $2.07 \times 10^{6} \pm 1.10 \times 10^{6} \mathrm{a}$ & $>100^{\mathrm{A}}$ \\
\hline 2 & $2.51 \times 10^{6} \pm 9.56 \times 10^{5} \mathrm{a}$ & $5.21 \times 10^{5} \pm 2.72 \times 10^{4} \mathrm{~b} *$ & $20.74 \pm 1.08^{\text {B }}$ \\
\hline 4 & $8.95 \times 10^{7} \pm 5.82 \times 10^{6} b$ & $2.90 \times 10^{5} \pm 7.70 \times 10^{4} \mathrm{~b} *$ & $0.32 \pm 0.09^{\text {в }}$ \\
\hline 8 & $1.58 \times 10^{8} \pm 3.37 \times 10^{7} \mathrm{c}$ & $4.37 \times 10^{4} \pm 1.04 \times 10^{4 b *}$ & $0.03 \pm 0.01^{\mathrm{B}}$ \\
\hline 12 & $3.20 \times 10^{8} \pm 2.25 \times 10^{7} \mathrm{~d}$ & $2.57 \times 10^{4} \pm 7.37 \times 10^{3 \mathrm{~b} *}$ & $0.01 \pm 0.00^{\text {в }}$ \\
\hline 16 & $3.39 \times 10^{8} \pm 2.75 \times 10^{7} \mathrm{~d}$ & $6.63 \times 10^{3} \pm 1.40 \times 10^{3 \mathrm{~b} *}$ & $0.002 \pm 0.00^{\mathrm{B}}$ \\
\hline 20 & $3.56 \times 10^{8} \pm 3.10 \times 10^{7} \mathrm{~d}$ & $3.47 \times 10^{3} \pm 6.66 \times 10^{2} \mathrm{~b} *$ & $0.001 \pm 0.00^{\mathrm{B}}$ \\
\hline 24 & $3.12 \times 10^{8} \pm 1.76 \times 10^{7} \mathrm{~d}$ & $3.83 \times 10^{3} \pm 1.63 \times 10^{3 \mathrm{~b} *}$ & $0.001 \pm 0.00^{\mathrm{B}}$ \\
\hline
\end{tabular}

7 


\section{Table 5 (on next page)}

Swarming zone of Salmonella Typhi in different concentration of WM36-CFCS

All values represented as mean \pm standard deviation $(n=3)$ and those connected by the same letters are not significant differences $(p<0.05)$. 
1 Table 5: Swarming zone of Salmonella Typhi in different concentration of WM36-CFCS

2 All values represented as mean \pm standard deviation $(n=3)$ and those connected by the same letters are 3 not significant differences $(p<0.05)$.

4

\begin{tabular}{cc}
\hline Concentration (\%) & Swarming motility zone (mm) \\
\hline Control & $45.00 \pm 5.00^{\mathrm{b}}$ \\
10 & $45.67 \pm 2.31^{\mathrm{b}}$ \\
20 & $0.00 \pm 0.00^{\mathrm{a}}$ \\
40 or MIC & $0.00 \pm 0.00^{\mathrm{a}}$ \\
\hline
\end{tabular}

5 


\section{Table 6(on next page)}

Fold changes in virulence gene expression in Salmonella Typhi in the presence of different inhibitory concentration of cell-free culture supernatant from Weissella confusa WM36

Values were expressed as mean \pm standard deviation of duplicate. The fold-change of virulence gene was analyzed using the comparative $\mathrm{Ct}$ method. The values derived from $2^{-\Delta \Delta c t}$ represent fold changes of samples in the abundance relative to the control sample (reference sample). The control sample has the $2^{-\Delta \Delta c t}$ value of 1 . The fold changes of each gene expression were used to compare between treatments and control. If others showed $<1$ indicates the level of gene expression is decreased or if $>1$ indicates that the level of gene expression is increased. All superscripts represented in the same gene, which indicated significant difference $(p<0.05)$ between treatments and control. 
1 Table 6: Fold changes in virulence gene expression in Salmonella Typhi in the presence of different 2 inhibitory concentration of cell-free culture supernatant from Weissella confusa WM36

3 Values were expressed as mean \pm standard deviation of duplicate. The fold-change of virulence gene was 4 analyzed using the comparative $\mathrm{Ct}$ method. The values derived from $2^{-\Delta \Delta \mathrm{Ct}}$ represent fold changes of

5 samples in the abundance relative to the control sample (reference sample). The control sample has the $2^{-}$ $6 \Delta \Delta \mathrm{Ct}$ value of 1 . The fold changes of each gene expression were used to compare between treatments and 7 control. If others showed $<1$ indicates the level of gene expression is decreased or if $>1$ indicates that the 8 level of gene expression is increased. All superscripts represented in the same gene, which indicated 9 significant difference $(p<0.05)$ between treatments and control.

10

\begin{tabular}{|c|c|c|c|c|}
\hline \multirow[t]{2}{*}{ Genes } & \multicolumn{4}{|c|}{ Fold change } \\
\hline & Control & $10 \%$ & $20 \%$ & MIC $(40 \%)$ \\
\hline hilA & $1^{\mathrm{a}}$ & $0.68 \pm 0.05^{\mathrm{a}}$ & $0.65 \pm 0.16^{a}$ & $0.69 \pm 0.21^{a}$ \\
\hline hilD & $1^{\mathrm{a}}$ & $0.69 \pm 0.01^{b}$ & $0.59 \pm 0.07^{b}$ & $0.40 \pm 0.01^{\mathrm{c}}$ \\
\hline sopB & $1^{\mathrm{a}}$ & $0.83 \pm 0.05^{b}$ & $0.28 \pm 0.03^{\mathrm{c}}$ & $0.12 \pm 0.01^{\mathrm{d}}$ \\
\hline sopE2 & $1^{\mathrm{a}}$ & $0.51 \pm 0.02^{b}$ & $0.03 \pm 0.01^{\mathrm{c}}$ & $0.02 \pm 0.002^{\mathrm{c}}$ \\
\hline $\operatorname{sip} A$ & $1^{\mathrm{a}}$ & $0.59 \pm 0.00^{b}$ & $0.29 \pm 0.08^{c}$ & $0.17 \pm 0.05^{\mathrm{c}}$ \\
\hline $\operatorname{sip} C$ & $1^{\mathrm{a}}$ & $0.81 \pm 0.02^{b}$ & $0.83 \pm 0.03^{b}$ & $0.17 \pm 0.02^{\mathrm{c}}$ \\
\hline$i n v F$ & $1^{\mathrm{a}}$ & $0.09 \pm 0.01^{b}$ & $0.04 \pm 0.002^{\mathrm{c}}$ & $0.02 \pm 0.00^{\mathrm{c}}$ \\
\hline sptP & $1^{\mathrm{a}}$ & $0.82 \pm 0.01^{b}$ & $0.62 \pm 0.03^{\mathrm{c}}$ & $0.13 \pm 0.02^{\mathrm{d}}$ \\
\hline $\operatorname{sdiA}$ & $1^{\mathrm{a}}$ & $0.79 \pm 0.34^{b}$ & $0.73 \pm 0.01^{b}$ & $0.15 \pm 0.01^{\mathrm{c}}$ \\
\hline $\operatorname{lux} S$ & $1 \mathrm{ab}$ & $1.18 \pm 0.19^{b}$ & $1.49 \pm 0.16^{\mathrm{b}}$ & $0.60 \pm 0.04^{\mathrm{a}}$ \\
\hline
\end{tabular}


Figure 1

Swarming motility of $S$. Typhi in the different concentration of WM36 cell-free culture supernatant.

(a) control, (b) $10 \%(\mathrm{v} / \mathrm{v}),(\mathrm{c}) 20 \%(\mathrm{v} / \mathrm{v})$ and (d) MIC (40\% v/v) of CFCS. The swarming motility zone was measured (not including dropped zone) and expressed as mean \pm standard deviation as previous described in Table 5. 

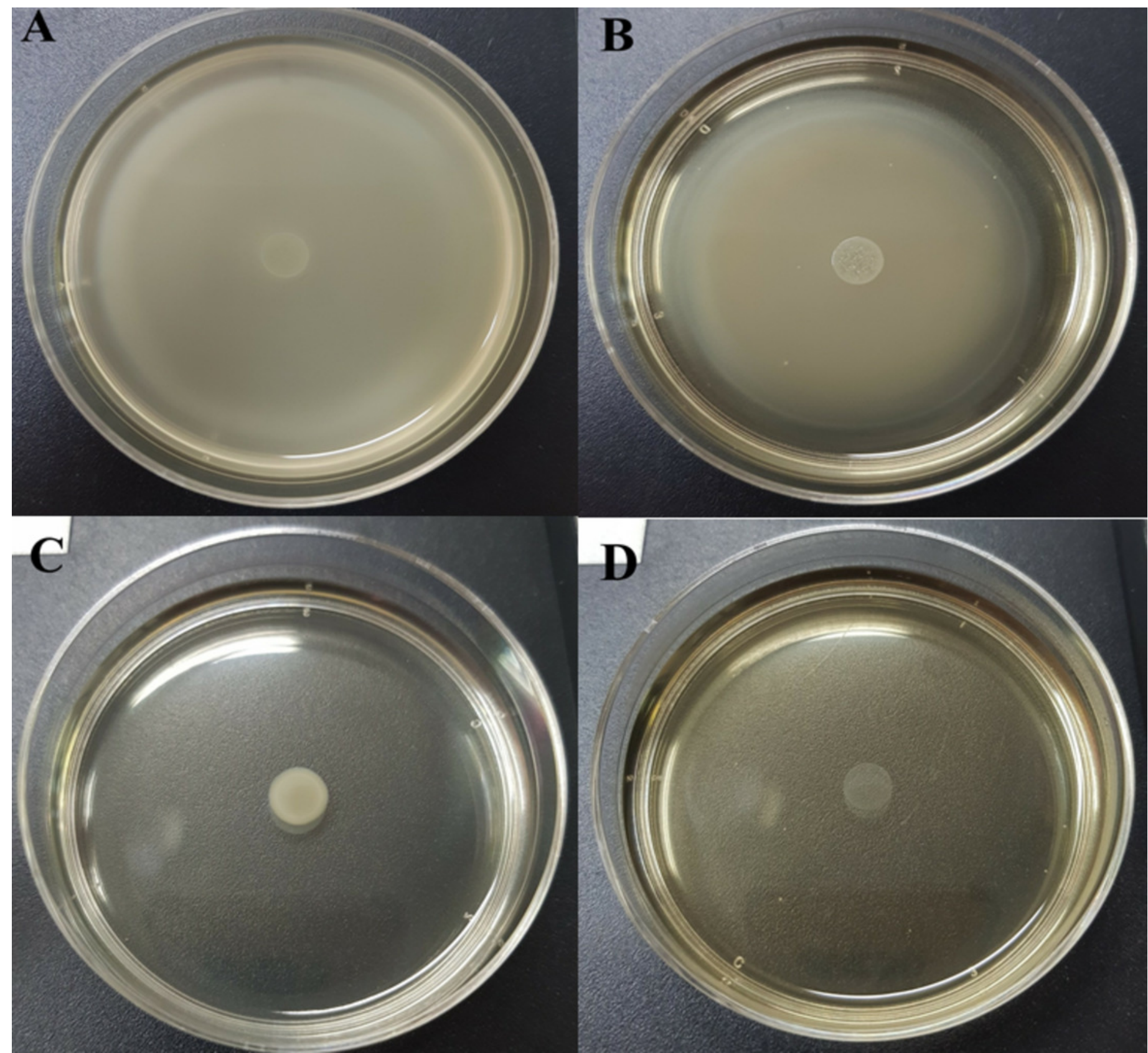
Figure 2

Intensity of biofilm formation attached crystal violet under microscopic visualization (10x magnification) of anti-biofilm activity of Weissella confusa WM36 cell-free culture supernatant against $S$. Typhi

(a) positive control, (b) 10\% (v/v), (c) $20 \%(\mathrm{v} / \mathrm{v})$, (d) MIC (40\% v/v) of CFCS and (e) negative control. 


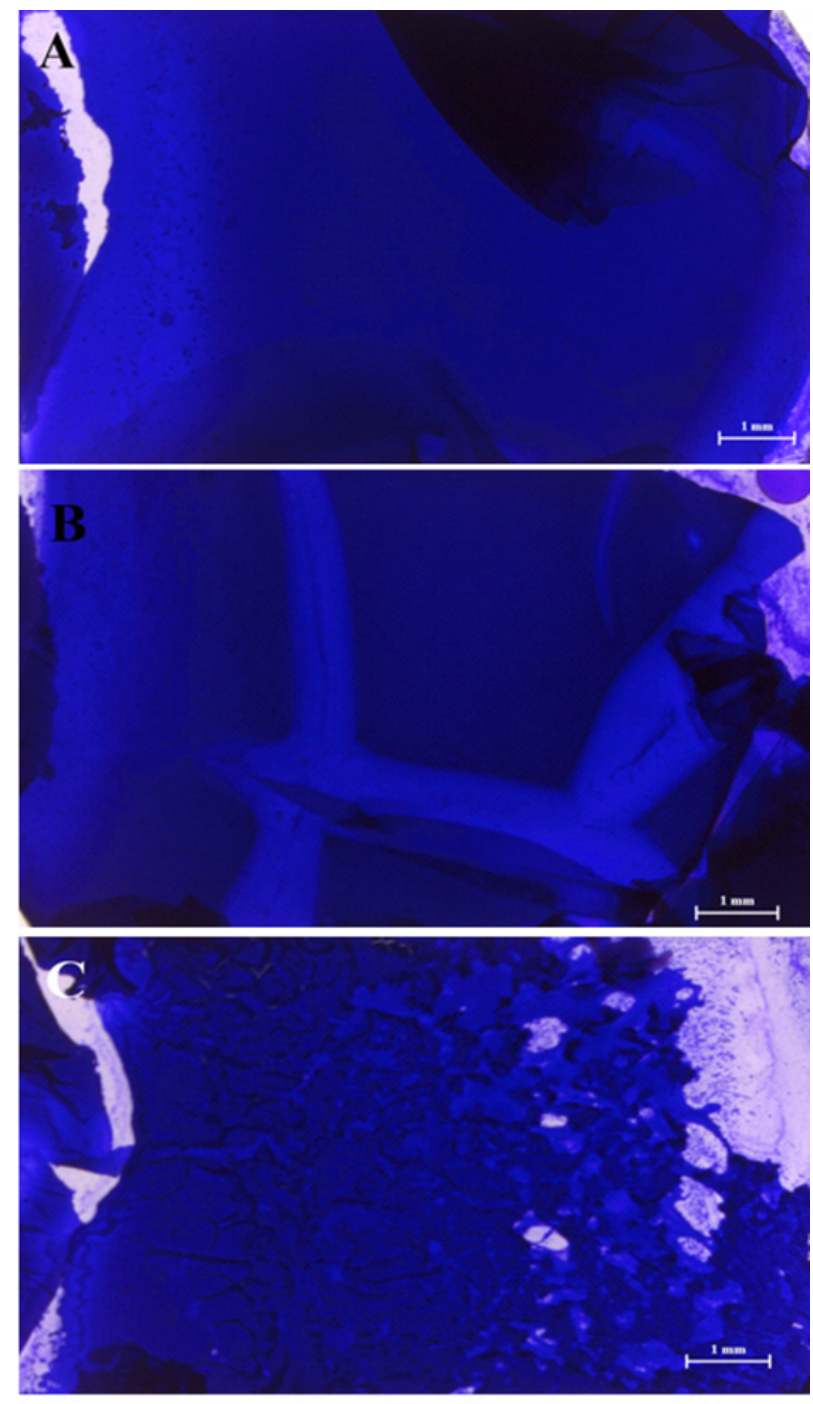

\section{D}

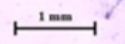

E

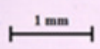

Peer] reviewing PDF | (2019:10:41941:1:0:NEW 18 Nov 2019) 